\title{
An Approach to Integrate Skills Development in Open Distance Learning (ODL) Environment: Part 2
}

\author{
T. S. Hlalele ${ }^{1}$, P. M. Mothibeli $S^{2}$, S. Sumbanyambe ${ }^{2}$ \\ ${ }^{1}$ Department of Electrical Engineering, University of South Africa, Pretoria, South Africa \\ ${ }^{2}$ Department of Industrial Engineering, University of South Africa, Pretoria, South Africa \\ (hlalets@unisa.ac.za)
}

\begin{abstract}
ODL education has been developing rapidly in Southern Africa recently. The system involves study that is not limted by geographical boundaries and in practice tend to extend knowledge beyond that is offered by contact or tradional univeristies. At the University of South Africa (UNISA), adoption of this method on theoretical knowledge has been successful. The practical component has not been effective, particularly in Electrical and Mechanical Engineering Curriculum. This has resulted in high volume of dropouts, contributed to unskilled graduates and unemployment growth within the academic space. In this paper, an emerging centered learner and a developed centered learner method is proposed. These two methods simulate unemployed and employed students who study part-time at the university in their first entry level. Employed are classified as developed centered learner (DCL) and unemployed, newly matriculated, as emerging centered learner (ECL). The results show a measure of correlation between the two groups of students in their learning method. Developed centered learner attained a better pass-rate than an emerging centered learner. A conclusion is made by drawing attention to the integration of practical curriculum elements and lasting understanding of theory in practice for ODL graduates.
\end{abstract}

Keywords - Engineering, Open learning, Curriculum and Practice

\section{INTRODUCTION}

The introduction of open distance learning (ODL) has changed the face of tertiary education worldwide [1]. ODL has overcome many barriers to learning that were experienced with traditional distance education, as it is more practical, flexible and effective, especially in an age of easy multimedia access [1]. Open Distance Learning (ODL) is a reach-out delivery idea with a high possible output to deliver to the South Africa and even countries across the boundaries. In particular, it is holistic apparoach that is inclusive in its service to population such as people with disadvantages or disabilities [2]. In its nascent stages, ODL seems to have set forth a furr in the academic arena. The main aim of ODL is to bring access to education to all the people. Through this mode, educational opportunities are disseminated to a large geographical population in and outside of the country [2].

In Africa, there are few existing ODL institutions of high learning. These include University of South Africa (UNISA), Zimbabwe Open University (ZOU), Open University of Tanzania (OUT) and the National Open
University of Nigeria (NOUN). Other African countries like Botswana and Zambia are in the process of launching ODL universities [3]. Both developed and developing countries are adopting ODL to meet the pedagogical demands of students in the $21^{\text {st }}$ century. Many educational institutions, especially in developed countries, are shifting from purely a face-to-face contact teaching model of higher education to an ODL model using information and communication technologies (ICTs) [3]. Within this ambit, many universities are therefore increasingly offering some type of online learning courses. It is increasingly seen, albeit a slow process, as a powerful channel for delivering educational opportunity to adults from all occupations. Open and distance education is best referred to as an educational process where learners take responsibility for their own learning [4]. ODL is rapidly gaining ground around the world [5]. Thereare several adavanatges as to why ODL is becoming popular in some Universities.

In essence, the globalization of ODL provides many prospects for developing countries for the recognition of their education system-wide goals. There are two main aspects which have led to an explosion of interest in distance learning: the growing need for continual skills improvement and reequipping; and the techno-logical developments that have made it possible to teach ODL [6]. The future of ODL, with particular interest to developing countries, may provide the much needed knowledge to support the growing social-technological development being experienced by developing countries. This may then vein-drip across such societies to finally reduce poverty ad other social ills. It has been noticed, especially over the past years, that the need for ODL is increasing due to the associated possibilities for new innovations and the adoption of Information and Communication Technologies (ICT) that results to the increased demand of knowledge to both literate and illiterate[7].

Despite all these wonders that come with ODL, there are pitfalls towards the full development of such an academic paradigm. The main problem with ODL, noted by many researchers, is that it offers monotonous, uniform education to everybody [8]. It is evident that the structure of ODL provides learners with the control over the time, however, learning at a distance is has challenges. Loss of student motivation due to the lack of face-to-face contact with lecturers, tutors, high tuition fees and lack of funding support from the university are among other 
barriers that may hinder the successful immenation of ODL [9]. In addition, many challenges arise in teaching science and engineering in ODL environment.

The prospect of obtaining a higher education qualification through full-time contact institutions seems to be a remote reality for the majority of black South Africans who were denied opportunities for higher education during apartheid [10]. The majority of this group is either in full-time employment, part-time employment, temporary posts, unemployed and at most unemployable [10]. In developing countries, ODL is viewed as a way to train qualified workers in their own socio-cultural contexts, with no need to migrate from one place to another [5]. However, ODL programs have a number of drawbacks such as high dropout rates and lack of individualized supervision to which we may add the many challenges that developing countries face, starting with access to adequate technologies so that students can enroll in the programs[5].

Past research, indicate clearly that there is a gap necessary to be closed on the transfer of skills within the higher education sector. Although providing academic excellence in teaching and learning is essential for the attainment of a degree, employers are looking for more than in-depth knowledge and understanding of relevant subject material from the graduates [11]. Numerous white papers from the department of higher education and training in South Africa have influenced largely upon higher education by emphasizing the need of undergraduates to be better prepared for the working environment. To achieve the adaptability required for working within different contexts and situations, exiting students are now required to have acquired some level of competence in a range of transferable skills to enhance their personal development and professional capabilities. To meet this demand at UNISA, students are offered opportunity to do practical work as a group at the near university of their choice, which has the memorandum of understanding (MOU) with UNISA. In most cases, this is a one-day session for all the experiments, which a student requires for that particular subject. The efficiency of this method is questionable, as students cannot obtain enough practical training as they do in theory. Additional universities will eventually be required in the context of meeting our enrolment targets. A particularly important role must be played by the expansion of distance education at both Unisa and mainly contact universities [12].

Many researchers highlight the value of technology in education while others emphasis more on shortcomings [13]. Students in Virtual Learning Environments may experience feelings of isolation [14], frustration, anxiety, and confusion [13], or reduced interest in the subject matter [15]. This is associated to the learning methods for students at ODL environment. Learner achievement has also been questioned. Some authors suggest that there is generally no significant distinction between open learning environments and face-to-face instruction. Table 1 depicts classification of learning environments.

\begin{tabular}{|c|c|c|}
\hline Dimesnsion & Definition & Comparison \\
\hline Time & $\begin{array}{l}\text { The timing of } \\
\text { instruction. VLEs } \\
\text { free participant } \\
\text { from time } \\
\text { constraints. }\end{array}$ & $\begin{array}{l}\text { When instruction } \\
\text { is delivered } \\
\text { asynchronously in } \\
\text { a VLE, } \\
\text { participants retain } \\
\text { control as to when } \\
\text { they engage in the } \\
\text { learning } \\
\text { experience. } \\
\text { Learners } \\
\text { determine the time } \\
\text { and pace of } \\
\text { instruction. }\end{array}$ \\
\hline Place & $\begin{array}{l}\text { The physical } \\
\text { location of } \\
\text { instruction. VLEs } \\
\text { free cate with } \\
\text { classmates and } \\
\text { instructors } \\
\text { through } \\
\text { networked } \\
\text { participants from } \\
\text { geo- resources } \\
\text { and a computer- } \\
\text { based interface, } \\
\text { rather } \\
\text { graphical than } \\
\text { constraints }\end{array}$ & $\begin{array}{l}\text { Participants access } \\
\text { the learning } \\
\text { material and } \\
\text { communicate with } \\
\text { instructors through } \\
\text { networked } \\
\text { resources and a } \\
\text { computer-based } \\
\text { interface, rather } \\
\text { than face-to-face } \\
\text { in a classroom. }\end{array}$ \\
\hline Space & $\begin{array}{l}\text { VLEs provide } \\
\text { access to a wide } \\
\text { array of resources. }\end{array}$ & $\begin{array}{l}\text { Although it is } \\
\text { viable to expand } \\
\text { the traditional } \\
\text { model of } \\
\text { classroom-based } \\
\text { instruction to } \\
\text { include the variety } \\
\text { of available in } \\
\text { VLEs (Leidner } \\
\text { and Jarvenpaa } \\
\text { VLEs provide } \\
\text { access to a 1993, } \\
\text { 1995), generally } \\
\text { these materials } \\
\text { remain only a } \\
\text { comprehensive } \\
\text { range of resources. } \\
\text { secondary } \\
\text { resource in face to } \\
\text { face contact } \\
\text { classroom } \\
\text { education }\end{array}$ \\
\hline Technology & $\begin{array}{l}\text { The collection of } \\
\text { tools used to } \\
\text { deliver learning }\end{array}$ & $\begin{array}{l}\text { VLEs technology } \\
\text { is used to deliver } \\
\text { learning material }\end{array}$ \\
\hline
\end{tabular}




\begin{tabular}{|c|c|c|}
\hline & $\begin{array}{l}\text { material and to } \\
\text { facilitate } \\
\text { communication } \\
\text { among } \\
\text { participants }\end{array}$ & $\begin{array}{l}\text { and to facilitate } \\
\text { learners } \\
\text { communication. }\end{array}$ \\
\hline Interaction & $\begin{array}{l}\text { The contact and } \\
\text { information } \\
\text { exchange between } \\
\text { learners and } \\
\text { lecturers. }\end{array}$ & $\begin{array}{l}\text { VLEs rely on } \\
\text { information } \\
\text { communication } \\
\text { technology to } \\
\text { create the venue of } \\
\text { knowledge } \\
\text { transfer } \\
\text { learning progress. } \\
\text { It is open in that, it } \\
\text { permits } \\
\text { communication } \\
\text { and interaction } \\
\text { between } \\
\text { participants. } \\
\text { Unlike traditional } \\
\text { contact education, } \\
\text { VLEs support } \\
\text { student-to-student } \\
\text { and student-to- } \\
\text { lecturer } \\
\text { connectivity } \\
\text { throughout the } \\
\text { learning in a } \\
\text { experience in } \\
\text { technology- } \\
\text { mediated settings. }\end{array}$ \\
\hline Control & $\begin{array}{l}\text { The extent to } \\
\text { which the learner } \\
\text { can control the } \\
\text { instructional } \\
\text { presentation. } \\
\text { Control is a } \\
\text { continuum } \\
\text { enabling the } \\
\text { design of varying } \\
\text { degrees of the } \\
\text { learner control }\end{array}$ & $\begin{array}{l}\text { A certain degree } \\
\text { of learner control } \\
\text { can be built into } \\
\text { traditional learner } \\
\text { can control the } \\
\text { classroom } \\
\text { instruction, but } \\
\text { VLEs have the } \\
\text { ability to provide } \\
\text { far more } \\
\text { personalized } \\
\text { instruction and a } \\
\text { controlled learner } \\
\text { than traditional } \\
\text { face to face } \\
\text { learning. VLEs, } \\
\text { however, provide } \\
\text { this flexibility } \\
\text { during instruction } \\
\text { as well }\end{array}$ \\
\hline
\end{tabular}

Table: 1 classification of dimensions of learning environments [16].

\section{METHODOLOGY}

Descriptive research survey method was implemented to collect data and catch the views of Unisa students.
Descriptive research can be either quantitative or qualitative. The rationale is to study and analyse the phenomenon happening at a specific place and time [17]. A descriptive research is concerned with conditions, practices, structures, differences or correlations that exist, views held, processes that are going on or trends that are apparent [17]. Quantitative research involves the data collection so that information can be quantified and subjected to statistical treatment in order to support knowledge demands [18]. The primary data collection method used in this study was through a structured questionnaire. An open ended questionnaire was used to supplement information. A written questionnaire tends to catch their unstated thoughts about the problem under discussion.

On this context, questionnaires were issued randomly to Electrical Engineering students at the University of South Africa in 2013. This was done during the practical sessions of Electrical Engineering I [4]. This was performed for Engineering 1 practical class, a first year level module where two groups were investigated. Experimental group students of 50 emerging centered learner (ECL) and 50 developed centered learner made one class. The first ECL group of students was allocated the practical session. This group was asked to do preparation for the experiments to be done during the session. They then presented to the lecturer who assessed the preparation. The students then carried out the experiments according to the instructions given to them by the practical instructor. Explanations were made where necessary. Control group of students 50 emerging centered learner and 50 developed centered learner who did not attend class.

Table I: Questionnaire distribution

\begin{tabular}{|c|c|c|}
\hline $\begin{array}{c}\text { Students } \\
\text { involved }\end{array}$ & $\begin{array}{c}\text { Data collection } \\
\text { method }\end{array}$ & $\begin{array}{c}\text { Number of } \\
\text { questionnaire }\end{array}$ \\
\hline $\begin{array}{c}\text { emerging } \\
\text { centered learner } \\
\text { (ECL) }\end{array}$ & questionnaire & 50 \\
\hline $\begin{array}{c}\text { developed } \\
\text { centered learner } \\
\text { (DCL) }\end{array}$ & questionnaire & 50 \\
\hline Total & & $\mathbf{1 0 0}$ \\
\hline
\end{tabular}


III. RESULTS

Fig.1: Performance statistics of DCL experimental group

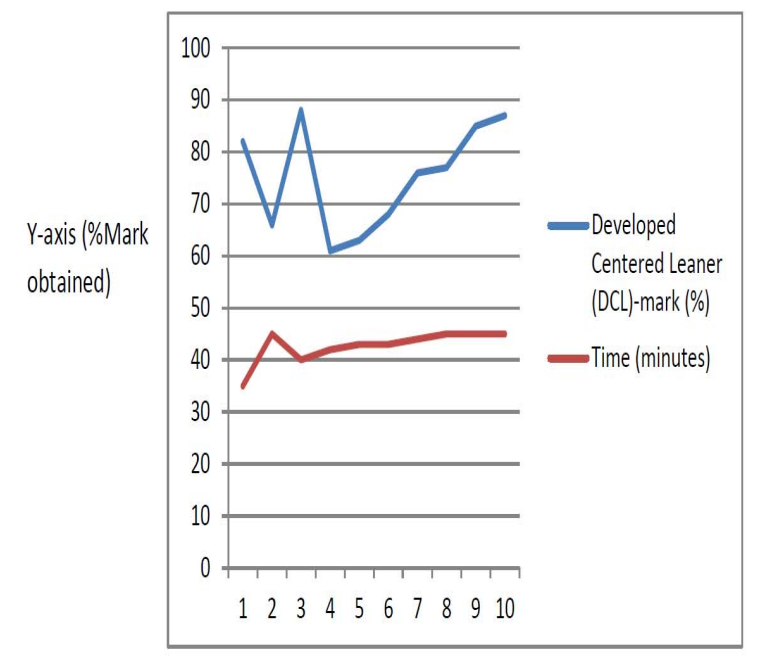

X-xxis (number of tests)

Figure 1: Experimental group of DCL

Fig.2: Perfomance statistics of ECL Experimental group

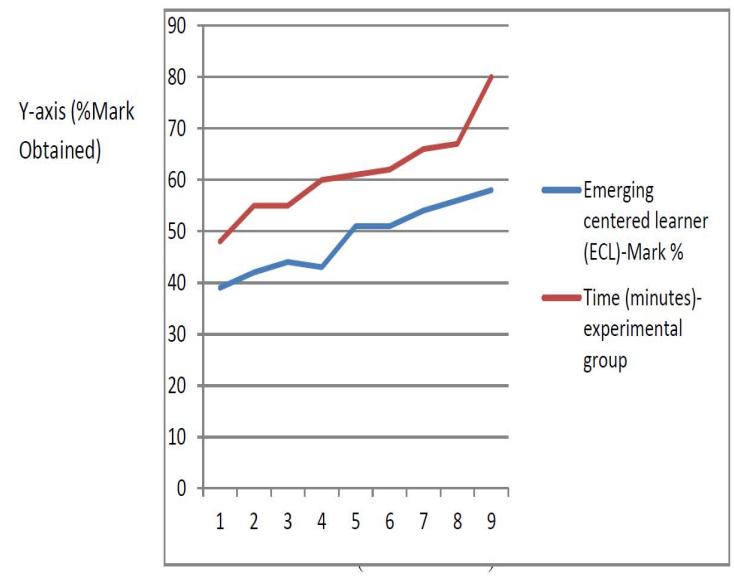

Figure 2: Experimental group of ECL

In figure 1 and 2 , it can be seen that the variation between marks obtained by DCL and ECL group is depended upon the time taken to complete the task given.

The DCL obtained higher marks than ECL although the time spe on experiments was less.
Fig.3: Illustrate the control group of DCL

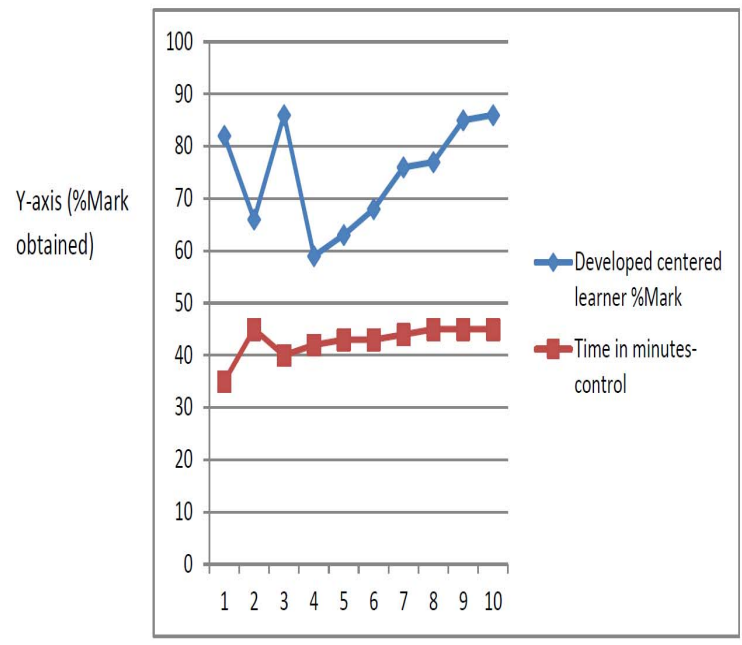

$X$-axis (number of tests)

Figure 3: Control group of DCL

Fig.4: Statistical analysis of control group of ECL

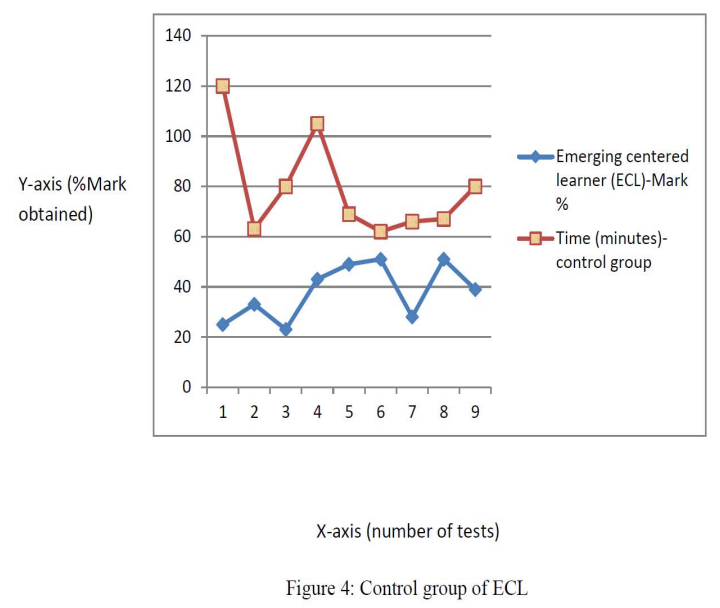

Fig.5: The overall total mark obtained by ECL and DCL
The Overall total marks obtained by ECL and DCL

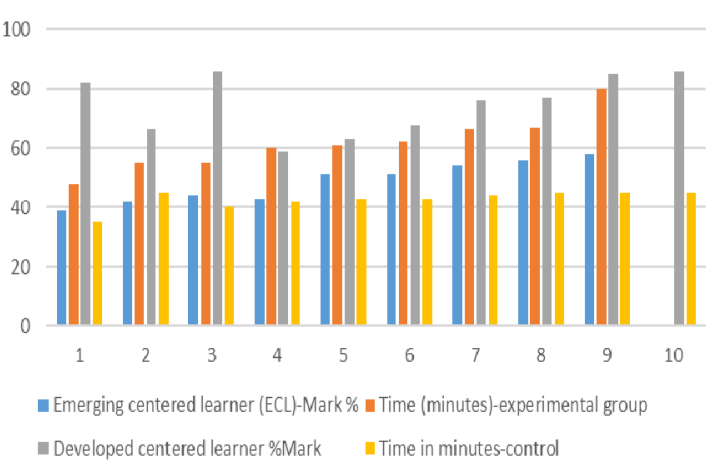


For figure 3 and 4, it can be seen that the marks obtained by the DCL are above the margin of $48 \%$ up to $88 \%$ while the ECL starts from the $20 \%$ margin up to $50 \%$.

\section{DISCUSSION}

Educating students from ODL environment requires the integration of theory and practice for successful skill impartation. It is quite a challenge in that theory is done separately and practical has a limited time. In most cases, practical experiments and industrial work help students to understand theory for the entire path of their career. Therefore, graduates who have attained both theory and practice excel in what they do and are more hunted by the employers. Students also seem to appropriate the value of developing skills in this manner as they recognize their performance in application of skills for learning further. This is found as a deciding factor for lectures to judge student's success even though they were not formally aware of putting more emphasis in teaching practical parallel with theory. Furthermore, we believe that the sequence which teaching approaches are applied for ODL should take into consideration whether a student is ECL or DCL type. Study materials should be designed to accommodate both types of students. Future research need to assess on the impact of internet-based virtual learning in improving the theoretical knowledge in practice.

\section{CONCLUSION}

According to the findings from the study, a developed centered learner has attained skills through industrial training in a relevant field of engineering. These particular learners have ability to work independently throughout the entire course of study. Experimental group of students who are named emerging centered learner take maximum time of one hour approximately to complete a 45 minutes task. As seen on Figure 1 of DCL experimental group, the minimum average mark obtained is 60 percent within 45 minutes whereas for ECL group the minimum average is 39 within 48 minutes. When considering the control group, developed centered learner mark correlates with the one obtained by the DCL experimental group. There is a rise in time for ECL in that the maximum time spends is almost three hours for the same task, which is performed by the DCL.

\section{REFERENCES}

[1] J. G. Ferreira and E. Venter, "Barriers to learning," pp. 1$12,2006$.

[2] P. Mutsvangwa and B. Mapuranga, "ODL University Inclusion Experiences of Students with Disadvantages in Zimbabwe," Int. J. Humanit. Soc. Sci. Educ., vol. 1, no. 4, pp. 37-47, 2014.

[3] M. C. C. Musingafi, B. Mapuranga, K. Chiwanza, and S. Zebron, "Challenges for open and distance learning (ODL) students: Experiences from students of the Zimbabwe Open University," J. Educ. Pract., vol. 6, no.
18, pp. 59-66, 2015.

[4] T. S. Hlalele, "An Approach to integrate skills development in Open Distance Learning ( ODL ) Environment," no. September, pp. 1-5, 2015.

[5] T. Karsenti and S. Collin, "Open and distance learning: What are the benefits for Africa, and what is its future?," E-Learn 2010--World Conf. E-Learning Corp. Gov. Heal. High. Educ., pp. 1869-1872, 2010.

[6] M. Moore and A. Tait, "Open and Distance Learning: Trends, Policy and Strategy Considerations," Unesco, vol. 23, no. 2, p. 96, 2002.

[7] C. B. F. Mnyanyi and T. S. A. Mbwette, "Final_paper_280Mnyanyi," 2009.

[8] A. Cristea and P. De Bra, "ODL Education Environments based on Adaptivity and Adaptability," Proc. E-Learn'02, vol. 8, pp. 232--239, 2002.

[9] H. Dzakiria, R. M. Idrus, and H. Atan, "Interaction in Open Distance Learning: Research Issues in Malaysia," Malaysian J. Distance Educ., vol. 7, no. 2, pp. 63-77, 2005.

[10] L. Moeketsi, "Open Distance Learning (ODL) in South Africa," no. March, pp. 1-345, 2015.

[11] D. Chadha and G. Nicholls, "Teaching transferable skills to undergraduate engineering students: Recognising the value of embedded and bolt-on approaches," Int. J. Eng. Educ., vol. 22, no. 1 PART I, pp. 116-122, 2006.

[12] Department of Higher Education and Training and Department of Higher Education Training, White Paper for Post-School Education and Training, no. 37229. 2013.

[13] N. Hara and R. Kling, "Student distress in web-based," Educ. Q., vol. 24, no. 3, pp. 68-69, 2001.

[14] steven R. Brown, "Open from the Rubric SAGE Social Science Collections . All Rights Reserved .," Q Methodol. Qual. Res., vol. vol.6 No.4, pp. 561-567, 1996.

[15] R. H. Maki and W. S. Maki, "Prediction of Learning and Satisfaction in Web-Based and Lecture Courses.," $J$. Educ. Comput. Res., vol. 28, no. 3, pp. 197-219, 2003.

[16] Gabriele Piccoli, "web-based virtual learning enviroment.pdf," pp. 401-426, 2001.

[17] U. Indonesia, D. L. Sari, and P. Pascasarjana, "Descriptive Research.," pp. 38-52, 2008.

[18] S. Raghavan and P. R. Kumar, "THE NEED FOR PARTICIPATION IN OPEN AND DISTANCE EDUCATION: The Open University Malaysia Experience," no. October, pp. 77-89, 2008. 